\title{
Across the threshold: negotiations of deservingness among unaccompanied young refugees in Sweden
}

\section{Ulrika Wernesjö}

To cite this article: Ulrika Wernesjö (2019): Across the threshold: negotiations of deservingness among unaccompanied young refugees in Sweden, Journal of Ethnic and Migration Studies, DOI: 10.1080/1369183X.2019.1584701

To link to this article: https://doi.org/10.1080/1369183X.2019.1584701

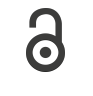

(C) 2019 The Author(s). Published by Informa

UK Limited, trading as Taylor \& Francis Group

曲 Published online: 20 Mar 2019.

Submit your article to this journal $\pi$

$\bigodot_{\text {CrossMark }}$ View Crossmark data $₫$

4

Citing articles: 3 View citing articles ¿ 


\title{
Across the threshold: negotiations of deservingness among unaccompanied young refugees in Sweden
}

\author{
Ulrika Wernesjö \\ Department of Social and Welfare Studies, Linköping University, Linköping, Sweden
}

\begin{abstract}
In the aftermath of the so-called 'refugee crisis' in 2015, unaccompanied minors have been depicted as potential threats and challenges to receiving countries in the Swedish public debate. Through narratives of unaccompanied youngsters from 2011 to 2012, this article will illustrate that these youngsters were already struggling with the ambiguous refugee figures of the 'deserving' and 'undeserving' prior to the events of 2015. By studying their narratives, I analyse how deservingness comes into play in how they constitute themselves as subjects. In their narratives, they describe themselves as responsible, hard-working youngsters in relation to education and future working life. Moreover, their narratives also illustrate how descriptions of diligence and agency are used in order to oppose the discourse figures of unaccompanied minors as threats or victims. I conclude by suggesting that these narratives can be seen as manifestations of conditional belonging centred on deservingness, which the youngsters negotiate also after they have been granted protection.
\end{abstract}

\section{KEYWORDS}

Unaccompanied youth; narratives; positioning; deservingness; diligence

\section{Introduction}

Since the increase in refugee immigration in 2015, which has been represented as 'the refugee crisis', forced migration and integration have been the focus of heated debates in Sweden. To a great extent these debates have been centred on asylum seeking minors arriving without their parents, in Sweden categorised as 'ensamkommande', which is a direct translation of the English term 'unaccompanied'. At first, there was widespread support for the asylum seekers arriving and people were organised to provide them with food, clothes and housing. However, this dramatically changed into a language of 'crisis'. In November 2015, the government declared the need for a 'breathing space' in asylum reception. Concurrently, disbelief and suspicion towards asylum seekers grew, with a normalisation of immigrant-critical discourses (Dahlgren 2016). Suspicions were raised about asylum seekers' claims and motives, but also regarding their perceived identities and culture. This was particularly the case for unaccompanied boys, who were portrayed in terms of a 'problematic masculinity' (cf. Herz 2018). Another suspicion 
concerned the minors' age, and there were descriptions of adults trying to pass as children in order to get their asylum applications approved (Stretmo 2014; Dahlgren 2016, 385). Thus, narratives of the unaccompanied child in need of protection were increasingly challenged by narratives of problematic youth, or, to use Fassin's (2005) words, went from 'compassion' to 'repression'. However, these suspicions did not originate in the language of 'the crisis' but are part of a longer history concerning migration in Europe (Lems, Oester, and Strasser 2019; cf. Fassin 2005). Finch (2005) describes a 'culture of disbelief regarding asylum seekers and their claims that is embedded in the asylum process, and shapes the ways in which asylum seekers are able to narrate their experiences in order to pass as 'legitimate'. Boundaries were, thus, drawn between legitimate and deserving asylum seekers, and those categorised as illegitimate and undeserving. Moreover, research has shed light on the ambiguous figure of the unaccompanied minor, who is simultaneously portrayed as vulnerable and in need of protection, and as strategic and untrustworthy (Crawley 2011; Stretmo 2014). Against this backdrop, there is a need to interrogate the ramifications of this ambiguous discursive figure and the disbelief asylum seekers face, for the ways in which unaccompanied youngsters tell their stories, and position themselves in their new situation.

In this article, narratives from unaccompanied youth with permanent residency collected in 2011-12 are used to illustrate that the unaccompanied minor as an ambiguous discursive figure was not an effect of the 'crisis' discourse in 2015. Rather it is part of the genealogy of the 'refugee crisis' that unaccompanied youth were struggling with also before then (Lems, Oester, and Strasser 2019). The narratives were collected as part of a research project that investigated unaccompanied youth's negotiations of belonging, with particular attention paid to social relationships, home and experiences of exclusion. When listening to their experiences and aspirations, it was also possible to hear them telling a story about who they were and strived to become. Importantly, these stories also reflected their position as newly arrived migrants in Sweden. Against this backdrop, the aim is to analyse how deservingness comes into play in how the young refugees in different ways constitute themselves as subjects through their narratives. In doing so, the article also contributes to a contemporary historical perspective on the ambiguous discursive figure of the unaccompanied minor that in many ways has come to represent the 'refugee crisis'.

\section{Forced migration and unaccompanied minors in Sweden}

Since 2010, Sweden has been one of the major receiving countries of unaccompanied asylum seeking minors within the European Union. In 2015, 35,369 unaccompanied asylum seeking minors arrived in Sweden, in comparison and 2199 in 2016 (Swedish Migration Agency (SMA) 2017). The majority of the children are boys aged 13-17 and one in six are girls. Internationally as well as nationally, Sweden has often been portrayed as a country that values human rights and equality, although this image has become increasingly debated (Pred 2000; Dahlstedt and Neergaard 2016). For example, even though Sweden has been described as having a generous policy towards refugees, it has become more restrictive since the 1990s (Abiri 2000; Hansen 2009).

During the second half of 2015, when increasing numbers of asylum seekers were seeking protection in Sweden, there was a dramatic shift in how the Swedish government, 
media and other actors approached the situation (Barker 2018). Initially, there was a comparatively generous attitude within the government towards the asylum seekers arriving, with prime minister Stefan Löfvén declaring that 'my Europe does not build walls' (Barker 2018). At this time, social movements mobilised in order to provide arriving asylum seekers with food, clothes and shelter. However, the political situation rapidly changed as a 'crisis' discourse was adopted by the parliamentary opposition, the government and the media in reports of municipalities and the welfare state being overstretched. On November 24th, the government declared the need for a 'breathing space' in the reception of asylum seekers. The government enforced stricter ID-controls at border passages in November and proposed restrictions in immigration policy (Swedish Government 2015). In June 2016, an interim legislation to delimit immigration, including temporary residence permits for asylum seekers and restrictions on family reunification, was approved by the parliament (SFS 2016:752). In the interim legislation, only those who can support themselves and their families financially after the temporary permit expires are eligible for permanent residency. Thus, the ability to work takes precedence over humanitarian protection and is a further example of how Swedish integration policy has become more focused on the labour market and employment (Dahlstedt and Neergaard 2016). Massive critique has been raised against the current legislation from organisations and network advocating refugees' and children's rights. Their struggle has lead to the additions to the law that increases the chances particularly for youth who are in school to stay in Sweden.

During this time period, migration and integration became a very heated topic in the political and media debate, and there was a shift towards a harsher rhetoric about asylum seekers, depicting them as a 'burden' on the welfare state and its limited resources, and as cultural 'others'. The resistance to refugee migration not only manifested itself in words; at the end of 2015, centres designated for asylum seekers had been set alight (Dahlgren 2016).

Against this backdrop, the situation and social conditions for asylum seekers and refugees in Sweden has changed dramatically since 2015. The fieldwork this article is based on was conducted in 2011-2012. In light of the last years' developments, the aim is to shed light on the genealogy of the 'refugee crisis' by looking at the ways young refugees positioned themselves before these events and changes in policy.

\section{Deservingness and the figure of the "refugee"}

In Sweden and the European Union today, (im)migration is highly regularised and there is tension in policy between providing protection in accordance with international conventions and treating it as a security issue (Abiri 2000; Hansen 2009; Holmes and Castañeda 2016). In this context, migrants and their claims are continuously categorised using dichotomies such as 'refugees'/'migrants', 'legitimate'/'illegitimate' as well as 'deserving'/ 'undeserving' (Watters 2007; Stretmo 2014; Crawley and Skleparis 2018). While the deserving are perceived as eligible for protection and care, the undeserving are perceived as untrustworthy and as making 'illegitimate and cynical attempts to pursue claims and gain access to a wide range of welfare benefits' (Watters 2007, 396; see Stretmo 2014; Holmes and Castañeda 2016). It needs to be stressed that categories such as these are not neutral orderings, neither do they reflect the realities of people who are labelled 
with them (Crawley and Skleparis 2018). Such suspicions about asylum seekers and their histories do however have effects and are part of a 'culture of disbelief (Finch 2005), in which their claims for protection are discredited and questioned. The overlapping dichotomies interplay with deservingness and shape the ways in which states and other actors treat people who migrate. These discursive framings of displacement are not only legal but also moral demarcations, and deserve to be critically examined as such (Holmes and Castañeda 2016, 16f). The key premise in this article is that these dichotomies continue to be of significance also after protection has been granted, and that the youth with permanent residence permits continue to position themselves in relation to them, although, as the analysis will illustrate, in somewhat different manners.

The debates on which individuals and groups are eligible for protection and aid, 'the moral economy of care', have a long history in Europe, which Thompson (1971) traces back to the sixteenth-century distinction between the deserving and undeserving poor (Watters 2007; cf. Fassin 2005). With the increasing focus on work in Swedish migration policy, there is a need to interrogate the implications this may have for how deservingness is negotiated by young refugees in their claims for belonging in the host country (cf. Lems 2019). The ambivalence Watters describes is also manifested in the way asylum seeking and refugee children are perceived. As children, they may be conceived as more deserving of care than adults, but with a focus on their inherent vulnerability there is a risk of not acknowledging their political asylum claims (Crawley 2011). With regards to the culture of disbelief, biological age has become a key issue, resulting in age-determination tests of unaccompanied minors and in discourses on 'beard boys' not revealing their 'true' age (Hedlund 2015).

As has been illustrated above, the categorisations of 'refugee' and 'deserving' are intrinsically connected, even though the demarcations between these categories are continuously negotiated. Rather than perceiving the refugee as an individual biography, Jackson $(2013,93)$ describes it as a discursive figure and as 'a site of intersubjectivity'. Hence, the refugee figure takes shape in social interaction and in a particular social and political context. Further, it involves an unequal power relationship, where the refugee is positioned as 'the other' (Jackson 2013, 94; cf. Back 2003, 351). The figure of the unaccompanied minor is, as has been described above, more ambiguous. Age and the overlapping dichotomies of 'legitimate refugee'/'illegitimate migrant' coincide in how they are portrayed as either vulnerable and passive victims in need of care or as strategic migrants (Stretmo 2014). Being treated as a victim, Jackson suggests, may obstruct their attempts to empower themselves in the host country $(2013,91)$, while being conceived as untrustworthy may entail other obstacles. There is, thus, call for interrogating how these figures and deservingness overlap and shape the ways in which the youngsters people construct narratives of self and of their situation.

\section{A narrative approach}

In this article, I focus on narratives of youngsters who have arrived in Sweden as unaccompanied asylum seeking minors, with particular focus on how they tell a story of self and of their situations. A narrative approach is used in order to capture the social process of storytelling as well as to analyse the stories they tell me about their experiences, situations and aspirations, as ways of telling me about themselves and of how they want be seen. 
Hence, narratives should not be understood as mirroring individuals' actual experiences or thoughts, rather, they are socially produced representations that call for our interpretation (Scott 1992; Eastmond 2007, 252). Narratives are 'a joint production' between the narrator and the listener, and relate to the particular social and political context in which they are told (Dwyer 1982; Eastmond 2007). Building on Arendt (1958), Jackson (2013, 31, 33) describes narratives and storytelling as belonging to the in-between space of intersubjectivity, and as activities in which we produce and reproduce ourselves as subject, who we are and who we want to become (cf. Bamberg 1997).

Telling one's story to another individual is an act in which things happen. Against this backdrop, the narrator may carefully select, downplay or exclude certain experiences and thoughts, while stressing others (Jackson 2013, 14). Narratives are thus situational and shaped by the interaction and power relation between the narrator and listener (Eastmond $2007,249)$. What is told and untold may change depending on the situation and who the listener is perceived to be. Thus, what is revealed in a narrative may be weighed against potential risks and against what it would be most expedient to say in a specific situation, and this is particularly be the case for marginalised groups (Jackson 2013, 13). Eastmond (2007) argues that the restrictive migration policy in the European Union, where asylum seekers' claims for protection are increasingly met with suspicion and disbelief, shapes and restricts the ways in which they are able to narrate their experiences (see Jackson 2013, 260). The youth in this article share histories of forced migration. Having been granted residency, their positions have to some extent been reshaped as they are faced with new challenges in making a life and future for themselves in Sweden. In order to understand their narratives, we need to interrogate them in relation to the social and political context, as well as in relation to larger narratives and discourses (Denzin 1997; Eastmond 2007, 252).

Through narratives, the youngsters position themselves and they do this within the discourses and social relations they are part of (Lassinantti 2014, 50; cf. Wetherell and Potter 1992). In this way, they both position themselves and are positioned by others in various overlapping and contradictory discourses (Daiute 2004). As has been noted earlier, people construct narratives in interaction with others, but this does not mean that they are free or are able to tell any narrative they want (Lassinantti 2014,50). What they say or do not say is not only shaped by the encounter with the listener and the power inequalities between them, but also constrained by the discourses that are available for them (Lassinantti 2014; Stretmo 2014). Discourse refers to 'socially produced forms of knowledge that set limits upon what it is possible to think, write or speak about a "given social object or practice"” (McHoul and Grace 1993, 31; cf. Foucault 1982). In particular, the focus here is on how the youth, through the narratives they produce in interaction with me as the listener, construct themselves in ways that they perceive as favourable or desirable in the context they are living in (cf. Rose 1999, xii).

\section{Method}

The article is based on narratives, collected through interviews, from 17 youths who arrived in Sweden as asylum seeking children unaccompanied by parents or care givers. At the time of the research, the participants were aged 16-21 and had been in Sweden between one and four years. However, one of them was 24 and had been in Sweden for eight years. All of them had received permanent residence permits. Most of the youth 
were from Afghanistan and Somalia, which reflects the two countries most asylum seekers came from at the time of the project, two came from Iraq and one from the Democratic Republic of Congo. Fourteen of them were male and three were female.

The study has been approved by the Ethical Vetting Board in Uppsala, Sweden. In order to protect the participants' identities, their names as well as other details that could potentially risk their anonymity have been changed or excluded. The youngsters were informed about the research project orally and in writing before giving consent. They were further informed that they could withdraw from participation at any stage, and refrain from taking about topics they did not want to. Consent was discussed again at the beginning of our individual meetings. The participants were given the opportunity to use an interpreter and speak their mother tongue, which six of them did.

The interviews centred on the youth's experiences of arriving and living in Sweden, with particular attention paid to social relationships, place, home, inclusion and exclusion. Education was included at a later stage as the narratives from the youth showed that it was a key issue for them. During the fieldwork my attention was increasingly drawn towards how statements from the participants, and topics they themselves brought up, were also narratives they told me about who they are and what they strive for. The themes included in the article were identified through the course of analysis as analytically different ways in which the participants positioned themselves in relation to deservingness and the ambiguous figure of the unaccompanied minor. The empirical material has been transcribed verbatim and the excerpts used have then been translated into English. In order to increase their readability some excerpts have been modified slightly.

\section{'We are also grateful'}

In this section, the focus is on the youngsters' narratives of being grateful, and the different ways in which they acknowledge the support and benefits they have received in Sweden. Marie was the first young refugee I met in the project. She came to Sweden at age 16 from DCR, accompanied by a man who knew her father and who after arrival left her at the SMA. When I ask her whether she ever felt unwelcome in Sweden, she refers back to when she arrived saying:

I have felt welcome in Sweden; I came without papers and nothing [...] they didn't know anything about me but they have taken care of me, they gave me a residence permit, clothes, food, everything [...] it is not that many countries that just take care of someone who suddenly arrives; I think they don't, not even in my country. I don't think they can do that so easily. [Marie]

Marie describes herself as a child arriving alone without any belongings, in a country that provided her with shelter and care without knowing anything about her. Some of the other youth also describe in positive terms having their basic needs met at the time of arrival, with particular emphasis on receiving clothes, food and residence permits. Moreover, Marie directs the narrative away from potentially negative experiences of not feeling welcome. By acknowledging the reception on arrival and comparing it with her country of origin, her narrative centres on gratitude, both for being granted protection and towards the care workers she met in the beginning. In her narrative, the hospitality she experienced when arriving in Sweden is construed as something that cannot be taken 
for granted and is compared with experiences from other countries or ideas of how it would have been elsewhere. The descriptions of Sweden are positive and in this regard Marie and the youngsters tend to use the dominant discourse on Sweden as a country that is peaceful, promotes human rights and provides shelter for refugees (Pred 2000).

Researchers who have conducted studies with asylum seeking unaccompanied minors in Sweden have found that the children describe themselves as content and grateful with the care they are given and seldom criticise Swedish society (Backlund et al. 2012; Lundberg and Dahlquist 2012). It has been suggested that the children, especially in the beginning, are in a situation where it is hard for them to be critical of the reception and care system, or that critique may be avoided due to unequal power positions (Backlund et al. 2012). Stretmo $(2014,245)$ had similar findings, but rather focused on how the youngsters constructed themselves as grateful, content and respectable young subjects. In the following narrative from Jawid, an 18-year-old who had been in Sweden for 18 months, gratitude is connected to having basic needs met, but also to the privileges he states he and the other youngsters at the residential home have. Jawid's migration from Afghanistan took several months, of which two were spent in a detention centre in another EU country. After release, he travelled to Sweden, where he was granted protection. When we talk about the situation at the residential home, he says that we have a better situation than Swedish kids'. When I ask him what he means by this, he says:

There are for example staff who say that 'I can't go with my kids to activities' like we do every week and that 'we don't cook wholesome food like lasagne every day for dinner', yeah it's things like that; we go to school, to the gym, get a bus pass; we get everything we want. [Jawid]

Based on what the staff have told him about their own children's economic situation, Jawid suggests that unaccompanied minors who live there are more privileged, since they are able to engage in more leisure activities than others their same age. Later, he also compares his situation with how it was, and would have been if he had stayed, in Afghanistan, and argues that he and other unaccompanied youngsters need to grab the opportunities they now have. In this way, he constructs himself as responsible for his own situation and future trajectories, and argues for the need for others in his situation to do the same.

The relationship between the refugee and the 'host' country is unequal and structured by power (Back 2003). Back refers to this as 'the grid of immigration', in which the refugee is forced to express gratitude to the host, which is portrayed as doing the migrant a favour. According to Back $(2003,351)$ 'the script is already written, whether one wants to perform the role or not'. With this in mind, it is worth considering to what extent the youngsters, and in particular Jawid, have encountered expectations from others that they should express gratitude, in some way or another. I suggest that these examples illustrate how power inequalities are played out in the interaction between myself, as a Swedish-born, adult researcher, and the youngsters, and how these shape their narratives, what they choose to say and how they do it.

In Haidar's narrative, gratitude is manifested although in a different way. Haidar left Afghanistan with his family as a young child and was later separated from them. At 15 he left Iran for Europe, walking great distances and travelling inside long-distance lorries. In Sweden, he was stopped by the police and was referred to a small municipality. When we talk about experiences of racism and discrimination, he says: 
they say 'yeah, refugees come and destroy' and I hear some who say that 'refugees only come to get financial assistance'. Some say that and I think 'what that kind of financial assistance is that'? You can't do anything in life if you don't work; I think it's good [in Sweden] and we're also grateful. They really help us, help me, and maybe someday you'll need me and I'll help you, and it is not as if we live to get financial assistance. We would die if we were in Afghanistan [laughs]; it was really bad to hear that kind of thing and they say 'you only come to take our jobs, social benefits' and that 'we pay and you get money' - those kind of things - it feels a bit weird. [Haidar]

By describing what he has heard and what 'they say', Haidar refers to immigrant-critical and racist discourses that depict refugees as illegitimate, not in need of protection and as people who only 'destroy' and 'come to get benefits'. He talks not only about himself but also a 'we' - refugees and Afghans - when he opposes these discourses and the way he, and others like him, are positioned as illegitimate and untrustworthy. In his narrative, emphasis is put on the impact of war, violence and poor future prospects in his country of origin. Simultaneously he rejects portrayals of asylum seekers as only migrating in order to receive benefits from the welfare state. By stating that 'we are also grateful', he acknowledges that he is aware of the need to express gratitude. In this way, he constructs himself and others from Afghanistan as legitimate refugees and rightfully deserving, with regards both to their previous experiences, and being diligent and grateful. Time and reciprocity are also brought to the fore, by his statement that he is willing to give back - 'I'll help you' - if someone else needs help in the future. In a similar way, Simon, 20, from Iraq, who had been in Sweden for four years, also describes that he is 'going to give back' by working, thus contributing to society, as a way of giving thanks for being granted residency.

Narratives of gratitude are more complex than first meets the eye. They may be manifestations of the unequal power relationship between the refugee and the host, as described by Back (2003). In addition, expressions of gratitude may be used in order to pass as deserving, by acknowledging the hospitality one has received. However, focusing on reciprocity and the will to help others is also a way for the youngsters to position themselves as responsible and as participants in the host country, if not now, then in the future. Expressions of gratitude, then, should not only be understood as characterising a subordinated position, but also as a way for them to talk about themselves as responsible, active and on their way to independence.

\section{Narratives of diligence}

When talking about aspirations for the future, many of the youngsters say that they want to have a 'normal' life, and to work and live in a quiet area. Tranquillity and safety may be understood as desirable in comparison to their previous experiences of war and conflict. In this section I will focus on how the youngsters talk about themselves and others in relation to living a 'normal' life, diligence and not getting into trouble. These issues are particularly raised by the young men, which suggests that they are more pressing for them; both in terms of being depicted as a potential threat or problematic youngster, and in terms of facing racialised discourse and stereotypes.

The youngsters all describe how they have struggled to get to know and become friends with youth they categorise as Swedish. Some of them suggest that the difficulties are based on how 'immigrants' or 'refugees' are depicted as different and problematic (Wernesjö 
2015). I met Livon, who had arrived from Iraq three years earlier at the age of 17, at the school he went to. When we talk about the relationship with other students he says 'Swedish pupils, I think they think we are bullies, or that we are rowdy, but we are nice. I don't know why they think that'. Opposing being portrayed as unruly or dangerous, and following with positive descriptions of himself and his friends, is a way of narrating that other youngsters use when talking about 2019. Stretmo $(2014,248 \mathrm{f}$.) also found that the unaccompanied minors in her study opposed themselves to the image of them as dangerous and problematic. As noted in the preceding section, refugee minors are at risk of being depicted as bogus and a potential threat to the nation state, and this is particularly the case for boys and young men (Bryan and Denov 2011; Hedlund 2015). This figure of the untrustworthy, problematic youth takes shape at the intersection of gender, ethnicity and age, and as Alexander $(2000,20)$ argues, young men with a migration background are construed as 'the ultimate symbol of crisis, deviance and threat'. Against this backdrop, narratives of being diligent and responsible may be a way to resist being depicted as the opposite, that is, being unruly, aggressive and a potential threat. However, by only focusing on what the youngsters position themselves against, there is an evident risk of not acknowledging their narratives as revealing how they want to be seen and what they strive for.

From a historical perspective, diligence was an ideal in the Swedish worker's movement during the nineteenth and twentieth centuries. Diligence, in this regard, can be described as comprising a strong work ethic, being responsible and sober, and has been intimately connected to class in Sweden (Ambjörnsson 1998; Sohl 2014). In the context of migration, diligence is brought to the fore in relation to application for formal citizenship. As prescribed by the law (SFS 2001:82), the applicant has to have been diligent and conducted him-/herself well in Sweden. This includes not having debts, not having committed any criminal offences and not being a threat to national security. Even though none of the participants were in the process of applying for citizenship, the emphasis on diligence and the ways it is conceptualised may be of significance in their lives and for how their narratives of self take shape in our joint interaction. Despite my efforts to reduce the unequal power relation between the youngsters and myself, a Swedish-born researcher in her thirties, it is naïve to think that this did not influence the way they presented themselves as, in this case, diligent or that our interactions were 'free from the effects of racism' (Back 1996, 24).

Diligence is also manifested in relation to staying away from certain places and avoiding getting into trouble. I met Idris the summer he was about to turn 18. He had come to Sweden from Somalia four years earlier, together with his cousin, who left him at the airport. At the time of our meeting he was living in a residential care home for unaccompanied minors just outside of a large city. We talk about the city nearby and he says:

\footnotetext{
Idris $\quad[. .$.$] It doesn't matter where I live, except for [stigmatised suburb].$

Researcher Why not there?

I Because I don't like [stigmatised suburb]. Yeah, if you live there you get all fucked up.

$\mathrm{R} \quad$ Why do you say 'all fucked up'?

I Like, what do you do? Guys who hang around and have nothing, guys you knew before. [...] I want to have a better life than that.
}

In order to live a diligent and 'good' life now and in the future, Idris expresses the need to orient himself away from friends he had before who now just 'hang around' and 'have 
nothing'. In order to stay on track with his aspiration of making a better life for himself and not getting into trouble, he describes the need to distance himself from certain relationships, settings and places, and instead orient towards others. The delinquency and lack of future aspiration he refers to is localised to a particular urban area. Ali, who came to Sweden from Afghanistan three years prior and who lives close by, also says the he avoids going there for similar reasons. Urban areas such as this were part of the 'Million Programme', a housing programme in the 1960s and 70s, but have since then been discursively construed as problematic and in terms of otherness, currently as 'particularly vulnerable areas' or 'areas of exclusion' (Dahlstedt and Lozic 2017). Both Idris' and Ali's narratives are influenced by such discourses that localise social problems to such certain areas. That Idris orients himself towards and away from certain relationships and places may be understood against the backdrop of his migration experience and aspirations of having a 'better life' than he would have had in Somalia, or that he describes the youngsters he refers to as having. Simon also talks about staying out of trouble by orienting away from certain settings, and describes how his parents always motivate him to stay 'on the right path' (Meloni 2019). By avoiding what they depict as negative influences, both Idris and Simon construct themselves as a diligent, law-abiding young men who take responsibility for their situations and futures.

In the narratives in this section, diligence and avoiding problems act as a way to make a better life for oneself, and as resource to oppose, and position, oneself against being depicted as a problematic youngster. Furthermore, statements about being diligent may also be used as a resource for the youngsters to position themselves as deserving.

\section{Responsible education-oriented self}

Together with learning the Swedish language, the importance of getting a formal education was particularly emphasised in the youngsters' narratives (cf. Hagström 2018). In contrast to the situation in their countries of origin, where access to education for many of them was limited, due to war or economic costs, education is free in Sweden. Against this backdrop, they describe education as an opportunity to make a better life for themselves. The focus in this section is on narratives of self in relation to education and future work aspirations, and these will be analysed both with regards to their migration experiences and to the Swedish welfare state context.

The youngsters establish that 'getting a job' is crucial not only for succeeding, but also for becoming self-reliant and making a life in Sweden. Further, in order to become employable in Sweden formal education is deemed necessary, not only by them but also in relation to demands from the labour market (Hagström 2018). There is a storyline that cuts across many of the narratives, in which education and employment open up a range of possibilities in the future (Chase 2019; Meloni 2019). For instance, when I ask Amina - a 16-year-old from Somalia who during the previous year had been living in a small village in the north of Sweden - where she would like to live when she is old enough to make her own decisions, she says 'you know, when you have an education you can get a job. When you have a job, you can live wherever you want'. In her narrative, education and, later, employment would enable her to make own individual choices on where and how to live. For others, they not only entail access to adequate or desirable housing, but also the possibility of starting a family. The narrative seems to follow a 
logical and responsible storyline, where one step cannot be taken before the former is achieved. The Swedish welfare state is characterised by its 'workfare approach' (arbetslinjen, Larsson 2015). The workfare approach can be traced back to the early twentieth century, but has become more salient with the neoliberalisation of the welfare state (Dahlstedt and Neergaard 2016). According to this policy, in order to qualify for welfare benefits individuals outside the labour market need to demonstrate that they are trying to find employment (Fernqvist 2013, 35). In the last decade, the workfare approach has reshaped Swedish integration policy into a primarily labour-market issue (Larsson 2015). The youngsters' narratives on education and work are to some extent a manifestation of how they adapt and position themselves within the discursive logic of the workfare policy in Sweden. In relation to Haidar's narrative, where he talked about suspicions that refugees are unwilling to work, deservingness is manifested in how they construct themselves as responsible, moral youngsters by demonstrating their willingness to work.

In the context of their migration experiences, they aspire to make a better life for themselves, and for their families. Even though there are some experiences and aspirations that cut across the narratives, the youngsters talk about their future hopes for education and work in different ways. Social positions according to age, educational background, class and gender may account for these differences. The stories may also transform or shift throughout the course of the narrative. At the beginning of my encounter with Idris, he talks about making music and says that he wants to become 'a superstar'. Later in his narrative, however, he talks about wanting to move on to university studies and become a medical doctor. Aspiring to be a superstar could in this regard be interpreted as an agebased positioning in his encounter with me, that is, being 'a teenager', while he later positions himself in accordance with being 'responsible'. Although, education and future aspirations are present in many of the narratives, some also say that they do not think about the future. This is particularly so in narratives from some of the younger participants, who will stay in school for a comparatively longer time than the others.

The youth in this study started attending the Swedish school system's introductory programmes for the newly arrived in their teens (ages 13-17 years). Against this backdrop, they identify certain obstacles and challenges that they face in the educational system as 'newly arrived'. Learning the Swedish language, qualifying for the national programmes in upper secondary school, as well as getting to know and get by in an educational system that is new to them, are represented as some of these challenges. In addition, their educational backgrounds vary. With regards to obstacles and challenges, the narratives are characterised how these can be overcome, by statements such as 'I will work hard' or 'you have to work hard'. In the following, Jawid talks about his future prospect and school situation.

\footnotetext{
Jawid Yes, I've always said that I want to be a teacher or a police officer but we'll see. I have to study a lot because I haven't gone to a regular school in my home country, so I have to study double as much as many others.

Researcher Do you feel stressed about that sometimes?

J No, I believe in myself really, I've never failed a test, not passed, and that's why I believe in myself and I don't want to mess up my future.
}

Before arriving in Sweden, Jawid had only two years of schooling in a Quran school. For this reason, he states that he has to work harder than others. At the same time, he says he is confident in his abilities, emphasising that he has never experienced any educational 
failures. In his narrative, he describes himself as a responsible young individual who works hard to achieve his goals, which is also what Stretmo (2014) found in her study. In a similar way, Rashid, 19, who grew up as an undocumented Afghan refugee in Iran, states that he is solely responsible for his educational achievements. With both parents dead, he left for Europe to make a better future for himself and his three younger brothers, who are still in Iran. 'It is all up to you', he says, and that it is not helpful to blame teachers or inadequate conditions at school. This could be a sign of a neoliberal school discourse seeping into their narratives, in which it is all about individual achievements. As such, emphasis on education and individual achievements may be a sign of the neoliberalisation of the Swedish welfare state and how integration policy has increasingly focused on employment. The youngsters people position themselves as capable and as 'taking responsibility for their future' in our interactions. This is also a way in which unaccompanied minors are depicted in public debate, as opposed to more predominant images of them as either victims or villains (Wernesjö 2014). Moreover, in their narratives, education and employment are construed as a meaningful route to becoming independent.

I will now turn to the youngsters' educational and occupational choices, and what is perceived as suitable or desirable in this respect. Some of them plan to undertake vocational programmes, while others aspire to move on to university studies. In the following narrative, Rashid puts the lack of unskilled job opportunities in Sweden to the fore:

Yeah, it was my friends who didn't want to go to school, so they started working in restaurants [pauses] or as cleaners or jobs like that. I cannot think, they have to go to school or I have to go to school. There are no jobs in Sweden; if you want to work with your hands, there are none really. [Rashid]

At the same time as he states that there is a lack of unskilled work in Sweden, he talks about friends who have these kinds of jobs in the service sector. In his narrative, he says nothing about the insecure working conditions or the modest wages that characterise such jobs, nor refers to status, but he may have considered these aspects. For him, such occupations are inconceivable, and therefore he needs to strive to get an education that would open up more qualified and desirable employment.

Many of the youth - male and female - say that they want to 'help others' by working in health care, law or in child- or elderly care. In this way, they not only construct themselves as responsible but also as care-taking, thinking about the needs of others, and helping others in adverse situations in Sweden or elsewhere.

\section{Concluding discussion}

Through narratives, people tell a story about their experiences and situations, of who they are and want to become. However, narratives are not mere reflections of the narrator's innermost thoughts or experiences. They are filtered and shaped by the encounter with the listener, the discourses available and the social and political context in which they are told. The social and political context for asylum seekers arriving in Sweden has been greatly reshaped since 2015, and is characterised by a polarised debate between those who advocate restrictions and closed borders, and those promoting a generous migration policy. In the midst of this debate are the unaccompanied minors, either represented as vulnerable children with claims for asylum, as a hard-working future 
workforce for Sweden or as untrustworthy young migrants. As this article illustrates, the youngsters I met in 2011-2012 were already struggling with this ambiguous figure, and positioned themselves within or against these representations in their narratives. Thus, the article contributes to putting the logic of the 'crisis' in a contemporary historial perspective, that sheds light on how the unaccompanied minor as a figure to care for or fear has a longer history in the context of migration in Europe.

The importance of being diligent, grateful, responsible and education-oriented runs through the narratives to a greater or lesser extent, and in relation to different aspects of the youngsters' lives. In this article I considered these to be a variation of ways in which deservingness is negotiated by the youngsters (cf. Lems 2019). Considering that narratives are produced in a particular context, the social conditions and discourses available shape what the youngsters say, but also what is left unsaid. Discourses are multiple, divergent as well as overlapping, and the youngsters position themselves within or against them throughout their narratives. I interpret descriptions of being responsible, educationoriented and hard-working as ways in which they position themselves as active in relation to the responsibilisation of individuals that characterises the contemporary Swedish welfare state and its policies on workfare and integration. Expressions of gratitude may on the other hand be manifestations of the unequal power relationship between the youth and the host country, and between them and me in our research encounter (cf. Back 2003, 351). However, their narratives are also made meaningful in relation to their experiences of migration. They describe trajectories away from war, conflict and lack of prospects for the future, to a place where they express the need to take advantage of the opportunities that are available to them.

Analytically, it is possible to see these different forms of narratives as distinct, although they tend to overlap: on the one hand as stories of who they are or want to be, and on the other as narratives in which they oppose labels inflicted upon them. The latter is particularly visible among the young men, who by narratives of diligence position themselves against racist and gendered portrayals of them as problematic. Further, I suggest that emphasis on agency, being hard-working and responsible may act as resistance against depictions of unaccompanied minors as particularly vulnerable (Wernesjö 2014). Altogether, I suggest that their narratives of self are used in order to oppose portrayals of migrants, and unaccompanied minors, as untrustworthy threats to the nation state and its welfare. The encounter between them as narrators and myself as the listener, and the unequal power positions we occupy, shape these narratives. However, by treating their narratives as jointly produced with an active listener it is possible to gain important insights into both how they constitute themselves as subject and of the social and political context in which narratives are produced.

What then are the ramifications of being granted protection and residency, that is, being categorised as 'deserving', for the continued negotiations of deservingness? Jackson $(2013,95)$ argues that the refugee is depicted as a 'deserving cause'. However, for the youngsters in this article, it is no longer a question of presenting legitimate asylum claims. Rather, focus is on how they conduct themselves in the present, and on their aspirations for the future. I suggest that deservingness is reshaped as they move from the categorisation 'asylum seeker', where focus is on vulnerability and claims for protection, to 'newly arrived', where they demonstrate deservingness by being and becoming active members of a particular political and social context. Narratives of responsibility, 
independence, and of a will to help others are potential expressions of this. However, these narratives may also act as efforts by the youngsters to reposition themselves, as individuals who no longer need to demonstrate deservingness. I suggest that the narratives shed light on the ways in which the young people are positioned in the Swedish welfare state. Their narratives can be seen as a manifestation of a conditional belonging, that they need to navigate as newly arrived youngsters. Moreover, I suggest that the narratives are a manifestation of a conditional belonging in the Swedish welfare state, which they are forced to navigate as newly arrived youngsters.

In light of the 'refugee crisis' and the dramatic developments since then, I suggest that it may be even more crucial today for unaccompanied minors, and asylum seekers in general, to narrate themselves as deserving in order to claim their rights to stay. Both against the backdrop of the public debates on migrations, and the restrictions enforced in policy (Lems, Oester, and Strasser 2019). These developments may also contribute to reshape how deservingness is conceptualised. The last years' social movement among unaccompanied youngsters, 'Ung I Sverige', where they claim their rights to stay by telling their stories on social media and on the streets could be a manifestation of this.

\section{Acknowledgments}

I am grateful to the editors for this special issue and the anonymous reviewers for their helpful comments on earlier drafts of this paper. Most importantly, I would like to thank the young people who participated in the research and were willing to share their stories with me.

\section{Disclosure statement}

No potential conflict of interest was reported by the author.

\section{ORCID}

Ulrika Wernesjö (D) http://orcid.org/0000-0003-3384-7518

\section{References}

Abiri, Elisabeth. 2000. "The Securitisation of Migration: Towards an Understanding of Migration Policy Changes in the 1990s: The Case of Sweden.” PhD diss., University of Gothenburg. Alexander, Claire. 2000. The Asian Gang: Ethnicity, Identity, Masculinity. Oxford: Berg.

Ambjörnsson, Ronny. 1998. Den skötsamme arbetaren. Idéer och ideal $i$ ett norrländskt sågverkssamhälle 1880-1930. 3rd ed. Stockholm: Carlssons bokförlag.

Arendt, Hannah. 1958. The Human Condition. Chicago: Chicago University Press.

Back, Les. 1996. New Ethnicities and Urban Culture. Racism and Multiculturalism in Young Lives. London: UCL Press.

Back, Les. 2003. "Falling from the Sky." Patterns of Prejudice 37 (3): 341-353. doi:10.1080/ 00313220307595.

Backlund, Åsa, Riitta Eriksson, Katarina von Greiff, and Eva-Marie Åkerlund. 2012. "Ensam och flyktingbarn: barnet och socialtjänsten om den första tiden i Sverige.” Research report 2012:1. Stockholm: FoU Södertörn.

Bamberg, Michael G W. 1997. "Positioning Between Structure and Performance." Journal of Narrative and Life History 7 (1-4): 335-342.

Barker, Vanessa. 2018. Nordic Nationalism and Penal Order. Abingdon: Routledge. 
Bryan, Catherine, and Myriam Denov. 2011. "Separated Refugee Children in Canada: The Construction of Risk Identity.” Journal of Immigrant \& Refugee Studies 9 (3): 242-266. doi:10. 1080/15562948.2011.592806.

Chase, Elaine. 2019. “Transitions, Capabilities and Wellbeing: How Afghan Unaccompanied Young People Experience Becoming 'Adult' in the UK and Beyond." Journal of Ethnic and Migration Studies. doi:10.1080/1369183X.2019.1584704.

Crawley, Heaven. 2011. “'Asexual, Apolitical Beings': The Interpretations of Children's Identities and Experiences in the UK Asylum System." Journal of Ethnic and Migration Studies 37 (8): 1171-1184. doi:10.1080/1369183X.2011.590645.

Crawley, Heaven, and Dimitris Skleparis. 2018. "Refugees, Migrants, Neither, Both: Categorical Fetischism and the Politics of Bounding in Europe's 'Migration Crisis'." Journal of Ethnic and Migration Studies 44 (1): 68-84. doi:10.1080/1369183X.2017.1348224.

Dahlgren, Peter. 2016. "Moral Spectatorship and Its Discourses: The 'Mediapolis' in the Swedish Refugee Crisis.” Javnost - The Public 23 (4): 382-397. doi: 10.1080/13183222.2016.1247332.

Dahlstedt, Magnus, and Vanja Lozic. 2017. "Managing Urban Unrest: Problematising Juvenile Delinquency in Multi-Ethnic Sweden.” Critical and Radical Social Work 5 (2): 207-222. doi:10.1332/204986017X14933953111175.

Dahlstedt, Magnus, and Anders Neergaard. 2016. "Crisis of Solidarity? Changing Welfare and Migration Regimes in Sweden.” Critical Sociology 45 (1): 121-135. doi:10.1177/ 089692051667520.

Daiute, Colette. 2004. "Creative Uses of Cultural Genres." In Narrative Analysis. Studying the Development of Individuals in Society, edited by Colette Daiute, and Cynthia Lightfoot, 111134. Thousand Oaks, CA: Sage Publications.

Denzin, Norman. 1997. Interpretive Ethnography: Ethnographic Practices for the 21st Century. Thousand Oaks, CA: Sage Publications.

Dwyer, Kevin. 1982. Moroccan Dialogues: Anthropology in Question. Baltimore: Johns Hopkins University Press.

Eastmond, Marita. 2007. "Stories as Lived Experience: Narratives in Forced Migration Research." Journal of Refugee Studies 20 (2): 248-264. doi:10.1093/jrs/fem007.

Fassin, Didier. 2005. "Compassion and Repression: The Moral Economy of Immigration Policies in France." Cultural Anthropology 20 (3): 362-387.

Fernqvist, Stina. 2013. "En erfarenhet rikare? En kvalitativ studie av barns strategier och barnfattigdomens villkor.” PhD diss., Uppsala University.

Finch, Nadine. 2005. "Seeking Asylum Alone." In The Asylum Seeking Child in Europe, edited by Hans E. Andersson, Henry Ascher, Ulla Björnberg, Marita Eastmond, and Lotta Mellander, 57-66. Gothenburg: University of Gothenburg /Cergu.

Foucault, Michel. 1982. The Archaeology of Knowledge and the Discourse on Language. Translated by A. M. Sheridan Smith. New York: Pantheon Books.

Hagström, Mirjam. 2018. "Raka spår, sidospår och stopp. Nyanlända ungdomars erfarenheter av mötet med Sverige och det svenska skolsystemet.” PhD diss., Linköping University.

Hansen, Peo. 2009. "Post-National Europe: Without Cosmopolitan Guarantees." Race \& Class 50 (4): 20-37. doi:10.1177/0306396809102994.

Hedlund, Daniel. 2015. “"Beard Boys”: Standing in the Way of a Transformation of the Self." In Invisible Boy: The Making of Contemporary Masculinities, edited by Camilla Hällgren, Elza Dunkels, and Gun-Marie Frånberg, 83-94. Umeå: Umeå universitet.

Herz, Marcus. 2018 (online first). "Becoming' a Possible Threat: Masculinity, Culture and Questioning Among Unaccompanied Young Men in Sweden.” Identities. doi:10.1080/ 1070289X.2018.1441692

Holmes, Seth M., and Heide Castañeda. 2016. "Representing the 'European Refugee Crisis' in Germany and Beyond: Deservingness and Difference, Life and Death." American Ethnologist. Journal of the American Ethological Society 43 (1): 12-24. doi:10.1111/amet.12259.

Jackson, Michael. 2013. The Politics of Storytelling. Variations on a Theme by Hannah Arendt. 2nd ed. Copenhagen: Museum Tusculanum Press. 
Larsson, Jenny K. 2015. "Integrationen och arbetets marknad: Hur jämställdhet, arbete och annat "svenskt" görs av arbetsförmedlare och privata aktörer." $\mathrm{PhD}$ diss., Linköping University/ Stockholm: Atlas akademi

Lassinantti, Kitty. 2014. "Diagnosens dilemman: Identitet, anpassning och motstånd hos kvinnor med ADHD.” PhD diss., Uppsala University.

Lems, Annika, Kathrin Oester, and Sabine Strasser. 2019. "Children of the Crisis: Ethnographic Perspectives on Unaccompanied Refugee Youth in and En Route to Europe." Journal of Ethnic and Migration Studies. doi:10.1080/1369183X.2019.1584697.

Lems, Annika. 2019. "Being Inside Out: The Slippery Slope between Inclusion and Exclusion in a Swiss Educational Project for Unaccompanied Refugee Youth.” Journal of Ethnic and Migration Studies. doi:10.1080/1369183X.2019.1584702.

Lundberg, Anna, and Lisa Dahlquist. 2012. "Unaccompanied Children Seeking Asylum in Sweden: Living Conditions from a Child-centered Perspective.” Refugee Survey Quarterly 31 (2): 54-75. doi:10.1093/rsq/hds003.

McHoul, Alec, and Wendy Grace. 1993. A Foucault Primer: Discourse, Power and the Subject. Carlton South, VIC: Melbourne University Press.

Meloni, Francesca. 2019. "The Limits of Freedom: Migration as a Space of Freedom and Loneliness among Afghan Unaccompanied Migrant Youth." Journal of Ethnic and Migration Studies. doi:10.1080/1369183X.2019.1584703.

Pred, Alan. 2000. Even in Sweden: Racisms, Racialized Spaces and the Popular Geographical Imagination. Berkeley: University of California Press.

Rose, Nicholas. 1999. Governing the Soul: The Shaping of the Private Self. 2nd ed. London: Free Association Books.

Scott, Joan W. 1992. “Experience." In Feminists Theorize the Political, edited by Judith Butler and Joan W Scott, 22-40. London: Routledge.

SFS 2001:82. Lag om svenskt medborgarskap [Citizenship Act]. Stockholm: Ministry of Justice.

SFS 2016:752. Lag om tillfälliga begränsningar av möjligheten att få uppehållstillstånd $i$ Sverige [Act on Temporary Limitations of the Opportunity to be Granted Residence Permit in Sweden]. Stockholm: Ministry of Justice.

Sohl, Lena. 2014. Att veta sin klass. Kvinnors uppåtgående klassresor i Sverige. Stockholm: Atlas akademi.

Stretmo, Live. 2014. "Governing the Unaccompanied Child: Media, Policy and Practice.” PhD diss., University of Gothenburg.

Swedish Government. 2015. Regeringen föreslår åtgärder för att skapa andrum för svenskt flyktingmottagande [The Government Proposes Measures to Create Breathing-Space in Swedish Refugee Reception] Press release, November 24. Accessed March 5, 2018. http://www.regeringen.se/ $\operatorname{artiklar} / 2015 / 11 /$ regeringen-foreslar-atgarder-for-att-skapa-andrum-for-svensktflyktingmottagande/.

Swedish Migration Agency. 2017. Aktuellt om ensamkommande barn och ungdomar [News on Unaccompanied Children and Youth]. Newsletter, March 2017. Accessed October 4, 2017. https://www.migrationsverket.se/download/18.4100dc0b159d67dc61433ac/1488546442781/ Aktuellt_om_mars2017.pdf.

Thompson, Edward P. 1971. "The Moral Economy of the English Crowd in the Eighteenth Century." Past and Present 50: 76-136.

Watters, Charles. 2007. “Refugees at Europe's Borders: The Moral Economy of Care.” Transcultural Psychiatry 44: 394-417. doi:10.1177/1363461507081638.

Wernesjö, Ulrika. 2014. “Conditional Belonging: Listening to Unaccompanied Young Refugees' Voices.” PhD diss., Uppsala University.

Wernesjö, Ulrika. 2015. "Landing in a Rural Village: Home and Belonging from the Perspectives of Unaccompanied Young Refugees.” Identities 22 (4): 451-467. doi:10.1080/1070289X.2014. 962028.

Wetherell, Margaret, and Jonathan Potter. 1992. Mapping the Language of Racism: Discourse and the Legitimation of Exploitatin. Hemel Hempstead: Harvester Wheatsheaf. 